\title{
Bodies count: the politics and practices of war and violent death data
}

\author{
Keith Krause Graduate Institute of International and \\ Development Studies, Geneva, Switzerland \\ keith.krause@graduateinstitute.ch
}

\begin{abstract}
In discussions of conflict, war and political violence, dead bodies count. Although the politics and practices associated with the collection of violent-death data are seldom subject to critical examination, they are crucial to how scholars and practitioners think about how and why conflict and violence erupt. Knowledge about conflict deaths - the 'who, what, where, when, why and how' - is a form of expertise, created, disseminated and used by different agents. This article highlights the ways in which body counts are deployed as social facts and forms of knowledge that are used to shape and influence policies and practices associated with armed conflict. It traces the way in which conflict-death data emerged, and then examines critically some of the practices and assumptions of data collection to shed light on how claims to expertise are enacted and on how the public arena connects (or not) with scholarly conflict expertise.
\end{abstract}

Key words: body counts, conflict, political violence, violent deaths

'We don't do body counts.' (General Tommy Franks)

\section{Introduction}

In discussions of conflict, war and political violence, dead bodies count. Western armies report each and every dead soldier on their side, with processions of coffins symbolising the human cost of war. War memorials - perhaps the most noteworthy being the Vietnam War memorial in Washington, DC, with its rows and columns of named dead - create icons for historical memory. Death counts are used to compare the relative horror of different wars. News accounts headline casualty figures as a means to convey the scale of human misery. Post-conflict assessments of (especially non-combatant) deaths are used to weigh and assess blame and responsibility, even criminal responsibility. And academics and 'conflict experts' generate data - including body counts - to produce 'scientific' knowledge that follows the Comteian dictum that from knowledge comes prediction; from prediction comes control. ${ }^{1}$ All of these different forms of conflict knowledge rely 
on a claim to expertise or, conversely, a requirement for 'expert knowledge' that in itself contains a set of assumptions, occlusions and - on occasion - leaps of faith. Although the politics and practices associated with the collection of violent death data are seldom treated as a subject in itself, or as worthy of critical examination, they are crucial to how scholars and practitioners think about how and why conflict and violence erupt. ${ }^{2}$

Bodies may count, but counting bodies has been a tricky business, and controversies over the number of victims in historical, recent and on-going conflicts, from the deaths in Central Europe between 1933 and 1945, to the mass atrocities in Guatemala and Cambodia, the massacres in Kosovo and the wars in Iraq and Syria, have raged in the public domain, in scholarly articles and in policy debates. Knowledge about these conflict deaths - the 'who, what, where, when, why and how' - is a form of expertise, created, disseminated, enacted and used by different agents, and is never neutral or truthful, and more often 'ignorant' in the sense that it is radically incomplete, often to the point of occluding more than it illuminates. We have, for example, only an imperfect understanding of the number of victims in several large-scale episodes of conflict and violence, including the Korean War, the Rwandan genocide of 1994, the mass killing of Pol Pot's Democratic Republic of Kampuchea (1975-79), or the wars in the former Yugoslavia (1990s), and the figures that are most widely cited are often incomparable and partial. ${ }^{3}$

Who generates and uses this knowledge and expertise, for what purposes, and how do they mobilise and perform their expertise in the political arena? This article comes at these questions from several different angles, highlighting the ways in which conflict expertise and, in particular, body counts are deployed as social facts and forms of knowledge that are used to shape and influence policies and practices associated with armed conflict and its public representations. It begins by tracing the way in which conflict-death data emerged, first in the public (state) and then scholarly or scientific realms, and then examines different ways in which body counts are used as part of a claim to expertise and form of knowledge in contemporary political and policy arenas, including not just the high politics of foreign ministries and policy makers, but also development actors, human rights advocates and international lawyers, non-governmental organisations (NGOs) and civil society. These claims to expert knowledge - some more academic, some more policy oriented - are not hermetically sealed, and examining critically some of the practices and assumptions of data collection can shed light on how claims to expertise are enacted and on how the public arena connects (or not) with scholarly conflict expertise. In a nutshell, I will argue that conflict knowledge in international relations and conflict studies, despite its aspirations to produce policy-relevant scientific knowledge, is (almost) entirely disconnected from political or public policy debates, and that the actors mobilising expertise in these debates often distance themselves from academically conventional 'conflict knowledge', while making strong claims to possess alternative and 'more relevant' expertise. By 'conflict knowledge' I mean those claims to expertise on the overall scope, scale, evolution, causes and consequences of contemporary wars and armed conflicts, rather than idiographic knowledge about specific conflicts, whether this be sociological, ethnographic, or historical. 


\section{Keith Krause}

I will unpack this argument in three steps:

- sketch briefly the origins of the concern with conflict deaths and body counts;

- detail the emergence and justification for conflict expertise as a scholarly or scientific form of knowledge, including in particular how war is defined and distinguished from other phenomena, and how 'conflict-death data' is deemed analytically or practically relevant;

- outline the parallel debate among policy-oriented communities that generate body counts to track human rights violations and influence criminal proceedings (including related to claims of genocide and mass killing), highlighting in particular the disconnect between macro-level scholarly conflict expertise and other scientific or 'evidence-based' knowledge about conflict casualties.

In the end, I will link this to a broader concern with how we understand the aetiology of conflict and the way in which the large-n analysis of quantitative data assumes that armed conflict and political violence are the result of linear causal processes, a warrant that has no backing. Overall, I want to illustrate the problematic shortcomings of how scholarly categories are constructed and how data is gathered in order to highlight just how 'ignorant' conflict expertise in international relations and conflict studies may be - at least in the sense of what it deliberately or otherwise ignores, occludes or cannot capture in the so-called 'scientific' study of war.

\section{Armies, states and soldiers: the origins of body counts}

Until the mid-nineteenth century, most soldiers died anonymously and were mourned locally. ${ }^{4}$ Soldiers in the seventeenth-century were mercenaries in commercial relations with state rulers or (by the eighteenth century) part of a permanent professional class of the state. By the Napoleonic era soldiers were increasingly (and often unwillingly) conscripts who fought and died uncounted. The approximately 380,000 soldiers of Napoleon's Grande Armée who died in the march to (and from) Moscow fell to their death by the roadside or were buried in mass graves, but were not accounted for in any systematic way. It fell to chroniclers such as Charles Joseph Minard to assess the nature of the losses, and his infographic 'Visual Depiction of French Army Losses in Napoleon's Russia Campaign, $1812-13^{\prime 5}$ is perhaps the first, and most famous, attempt to visualise spatially and numerically the war losses in the epic journey of Napoleon's armies. Detailed though it is, it says nothing about Russian, other nationalities or civilian victims, which may have totalled another 600,000 deaths that are invisible in this visualisation. ${ }^{6}$ Similarly, the estimate of 618,000 casualties of the American Civil War is based on imperfect demographic, recruitment and casualty records and, although enlistment and casualty records were kept on both sides (and there was an obligation to pay for funerals), there were no formal identification tags for soldiers, and no official accounting of deaths by the state(s). ${ }^{7}$

Two forces - mass conscription into national armies and the development of modern administration - came together in the late nineteenth century to make 
body counts a preoccupation of modern armed forces. ${ }^{8}$ The development of more effective military bureaucracies, military pension and care systems and other administrative structures meant that by the late nineteenth century, and certainly by the First World War, counting their own casualties became part of the business of states engaged in war fighting. Alongside this, the notion of the citizen-soldier fighting for the nation demanded respect for (and sometimes reparation for) the human sacrifices offered to Mars. The Franco-Prussian War of 1870, for example, marked the first time in which war deaths were commemorated as such, and was 'in many respects a manifestation of a much wider cultural evolution in attitudes towards death in war, where the loss of young men had come to represent at once the loss of a valued citizen and a human tragedy'. ${ }^{9}$ The Treaty of Frankfurt required both France and Germany to respect and maintain war graves on their soil. Countless war memorials with names inscribed upon them have subsequently dotted the European landscape as silent witnesses to this new form of performative respect for sacrifice to the nation. This idea of bearing witness to the victims of war - usually only the soldiers who fought in it, including the so-called 'unknown soldiers' - involved an attempt at individual naming and recognition. It will return as part of the contemporary story of counting casualties - but today with implications well beyond battlefield deaths.

Counting the non-military casualties of war was not the job of the state - or of anyone - until the latter half of the twentieth century. If war had been a battlefield confrontation between opposing forces distinct from the civilian population, a neglect of civilian casualties might have been justified or understandable. But predation upon and victimisation of civilians was always a concomitant of war and civilian casualties included both direct victims of violence, such as in the sack of cities or twentieth-century aerial bombings during Second World War, and - more often - indirect victims of violence who died after being deprived of access to food, shelter, water or basic necessities as a result of living in war-ravaged areas, especially when marauding armies requisitioned supplies in their passage. The numbers of indirect victims (excess mortality for demographers) could be considerable, and considerably greater than those of direct victims of violence: up to one third of the population of the German territories died during the Thirty Years' War; five to six million people may have died of starvation or deprivation in the Korean War; and perhaps more than three million died of similar causes in the eastern regions of the Democratic Republic of the Congo (DRC) between 1999 and 2003. ${ }^{10}$ In each of these cases the number of violent deaths was a small percentage of the total: in the DRC, perhaps around 10 per cent; in Korea, around 15 to 20 per cent. Yet such comprehensive body counts of the human costs of war were of interest only to social historians or demographers, far-distant experts whose expertise was seldom brought to bear on immediate problems.

When states did engage in body counts, controversy followed. In the Vietnam War (1965-75), body counts were (mis)used as an indicator of progress in the war, and the US Department of Defense ultimately estimated that 950,765 (!) communist fighters were killed. These figures (allegedly for enemy combatants) were, however, likely inflated and included a significant percentage of civilian non-combatants. 


\section{Keith Krause}

The pressure to produce body counts as a measure of results led to all sorts of perverse outcomes; overinflating the figures was perhaps the least pernicious. Other official American estimates put the total of Vietnamese (North and South) war dead - civilian and combatant - at upwards of 1.2 million, while the Vietnamese government proposed the figure of 3.1 million. The best demographic and population survey estimate, however, is 882,000 , suggesting that both sides overinflated their estimates, but for different reasons. ${ }^{11}$ The Vietnam experience created in the US armed forces at least a clear aversion to body counts, with the result that by the 1991 Persian Gulf War the military exercised near-total control over what Margot Norris has called military necrology, and pre-censored all battlefield reporting, in part to minimise reporting of civilian casualties. ${ }^{12}$ Similar struggles over numbers took place in the war in the former Yugoslavia, with the final tallies (around 100,000 ) much lower than the figures bandied about to win the media war (which ranged from $250,00-329,000$ at the upper end). ${ }^{13}$

\section{Body-count expertise emerges}

The development of systematic expertise on the study of war took place in the early twentieth century and included 'body counts' as one of its core elements. The purpose was, for most, normatively driven, but with an 'expert purpose'. In the work of scholars such as Lewis Richardson and Quincy Wright, this work was driven by three broad motivations:

- to count and classify all relevant occurrences of a particular phenomenon;

- to test simple causal models to uncover linkages and explain the 'variation' in outcomes;

- to generate 'politically-relevant' knowledge (peace research) that could be used to reduce the human, economic and social costs of war and violence.

These three elements characterised what its proponents call the 'scientific study of war', and all were present from the outset in the work of Lewis Richardson and his collection of Statistics of Deadly Quarrels, and have continued until today, most prominently in the various outputs of the Uppsala Conflict Data Program (UCDP). ${ }^{14}$

Expert 'conflict knowledge' from the scientific study of war has not been purely scholastic, and has - as was intended by its proponents -been prominent in some recent public policy debates. The World Bank 2011 World Development Report, for example, (subtitled Conflict, Security, and Development) relied almost entirely on data and analysis from the UCDP to support its claims concerning the scope, scale and trends in armed conflict, and one of its headline statistics was that the annual number of battle deaths from civil war fell from more than 160,000 a year in the 1980 s to less than 50,000 a year in the $2000 \mathrm{~s}^{\prime} .{ }^{15}$ Parenthetically, this report was a crucial (and planned) intervention on the path towards the UN Sustainable Development Goals of 2015, where the most controversial (and last agreed) goal concerned, inter alia, the issue of peace and security, with the headline target for 
the international community to 'significantly reduce all forms of violence and related death rates everywhere'. ${ }^{16}$ The Organisation for Economic Co-operation and Development (OECD) has also relied on UCDP data for its analysis of state fragility within its International Network on Conflict and Fragility, which monitors international engagement with fragile and conflict-affected states in order to enhance programming and policy making. ${ }^{17}$ The 'conflict knowledge' produced by these researchers is not drawn upon by accident; it is used mainly because it resonates well within institutional circles (the World Bank and OECD) that rely heavily on the kinds of macro-level general and abstract, but statistically 'reliable', knowledge produced by economists. Yet, at all levels - from the policy-related to the academically oriented and purely theoretical - scholars in this tradition have generated conflict knowledge that is weak - or ignorant -both in the narrowly empirical sense (how and what we count) and in conceptual terms (what are we trying to explain or understand). Two illustrations that highlight the resulting 'ignorant expertise' concern how the object of study - 'war' - is understood and the way in which its human impact is calculated.

\section{Producing war: establishing the ontological prior}

Scholarly expertise rests upon establishing the boundaries of the phenomenon in question, and the scientific study of war presumes the ontologically distinct and recognisable status of 'war' as its object of analysis. From the outset, conflict experts such as Lewis Richardson adopted a broad approach, defining wars as simply a subset of 'deadly quarrels', which included everything from homicide upwards. ${ }^{18}$ Such a definition can encompass everything from inter-state disputes to civil wars, to banditry, inter-group conflict and criminal violence. This holistic approach to violence was deliberate, and justified by Richardson, for example, on the grounds that he wanted to explore 'whether there is any statistical connection among these traditionally separate topics'. ${ }^{19}$ The data available dictated, however, a much narrower focus for more scientifically oriented scholars intent on working with a tractable universe of cases, and the analytical focus thus became first on 'wars' defined as events with more than a hundred deaths, and subsequently, on inter-state wars with more than a thousand battle deaths. ${ }^{20}$ These positions have been reflected throughout subsequent scholarship, and most particularly with the Correlates of War (COW) and the UCDP datasets. But Richardson's crucial insight - that forms of violence may be linked in complex ways - has been completely occluded in conflict-knowledge generation in international relations and conflict studies, where the dependence on particular forms of knowledge (data) production and the specialisation of subject areas and methods have led to a situation in which 'the study of each type of political violence is now a world of its own, largely detached from the developments in research on other types of political violence ... [and] it has become increasingly difficult to ... see the connections between the similar types of violent behaviour'. ${ }^{21}$

The first - and widespread - critique of this move concerns the threshold for classifying something as a war. The clearest distinctions rested upon the 'stateness' 
(or state-claimant) nature of the participants and the legality of their use of force, with primacy given to inter-state war, or civil wars in which both parties made claims to legitimate stateness. This obviously excluded most colonial or imperial wars (these were counted as 'extra-systemic', but seldom used for formal analyses), as well as large-scale sub-state violence. ${ }^{22}$ For example, in studies that focused on variables such as trade, borders, form of government, military spending etc., the 'stateness' of the main actors was critical. In the contemporary period, one result has been a tendency to count relatively low numbers of wars in recent years and to chart a broadly declining, then stabilising trend for armed conflicts. Hence the UCDP data for 2012 (for comparison with figures below) claims that there were seven on-going 'wars' (more than one thousand battle deaths) and thirty-three active conflicts with at least twenty-five battle deaths, noting that 'In 2012, two out of five people dying in battles, died in Syria'. ${ }^{23}$ The trend analysis is also clear: 'relative to the peak year of 1991, which saw 52 active conflicts, the number is down by as much as almost 37\%, ${ }^{24}$ Obviously, such trends can easily be - and have been reversed, and a trend line is not an explanation.

This form of conflict expertise also generally ignores large-scale violent struggles between actors neither of whom were making a state-claim; these are either treated as 'non-state wars' or omitted entirely from the analysis. In the most recent COW dataset (v.4, 2010), for example, only one such war is listed since 1975 (to 2007): the Hemda-Lendu war of $1999-2005$ (in the Eastern DRC). ${ }^{25}$ This seems hardly to accord with our understanding of the nature of violence either in the Eastern DRC (which pitted various non-state groups, often with state backing, against each other) or in other places where non-state groups struggle with each other for control of territory, such as the cartel wars in Northern Mexico, which have claimed tens of thousands of lives. This ought to give pause, for two reasons. First, the 'groupness' that is presumed in these classifications requires that the violent actors resemble state actors in their organisation, command and control and - most importantly - possess broadly political or ideological aims. This seems to exclude the vast majority of contemporary sub-national violence that, while it may not be motivated in a narrow sense by political aims, still has significant political consequences. It is unclear, for example, why the large-scale land and resource conflicts between tribal groups in Yemen, which have cost up to four thousand lives per year in recent years, would be excluded from an accounting of large-scale political violence. ${ }^{26}$

Second, it provides a highly incomplete picture of the scope and scale of contemporary organised or political violence, or of trends in armed violence in general. Narrow definitions might make sense in a world in which large-scale violence was progressively subordinated to state control, public/domestic order was established within (mainly European) states and the greatest risk of dying violently that an individual faced was most likely as a consequence of war. But they do not well capture the nature of large-scale conflict and violence in many parts of the world today. Figure 1, for example, provides a snapshot of lethal violence in 2012 per 100,000 population and illustrates that most lethal violence occurs in places and under circumstances that are not formally considered 'wars' by conflict scholars. 


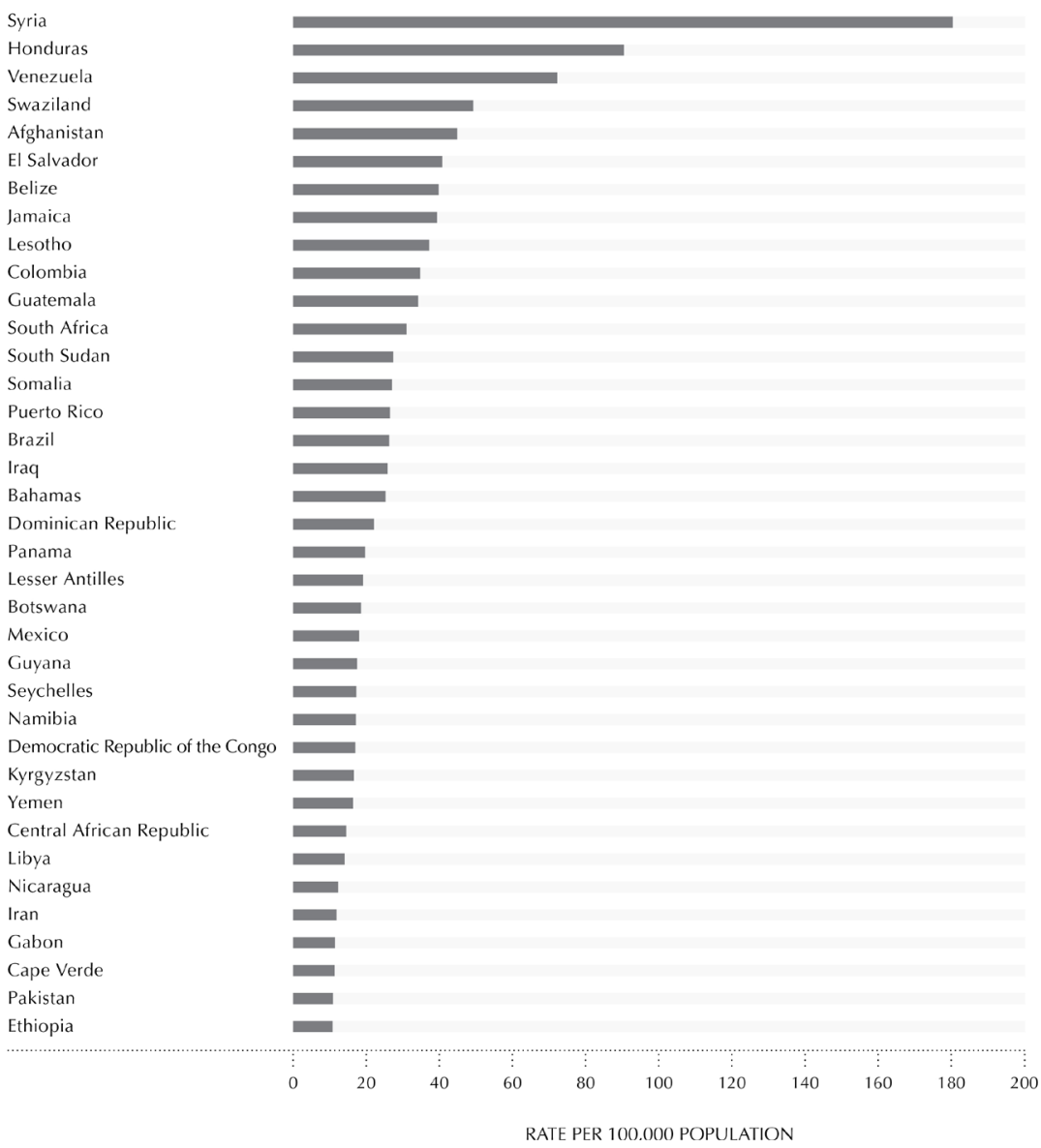

Figure 1 Lethal Violence Rates per 100,000 Population (2012)

Source: K. Krause, et al. (eds) Global Burden of Armed Violence (Cambridge, Cambridge University Press, 2015).

Approximately 508,000 people die violently around the world each year (excluding suicides) - in conflict and non-conflict violence - for an overall global 'violent death rate' of 7.2 per 100,000 . These deaths are, however, unevenly distributed: the thirtysix countries in the figure all have rates greater than ten deaths per 100,000; twelve have rates greater than thirty per 100,000. While some of the most violent countries are war zones (such as Syria, Afghanistan or South Sudan), many more are found in Latin America and the Caribbean. Honduras, Venezuela and El Salvador are all more dangerous than Afghanistan; Colombia, Jamaica, Pakistan, Mexico and Guatemala also rank high on the list of most-violent places. Other states with high levels of violence that are spatially very concentrated, but which have large popula- 


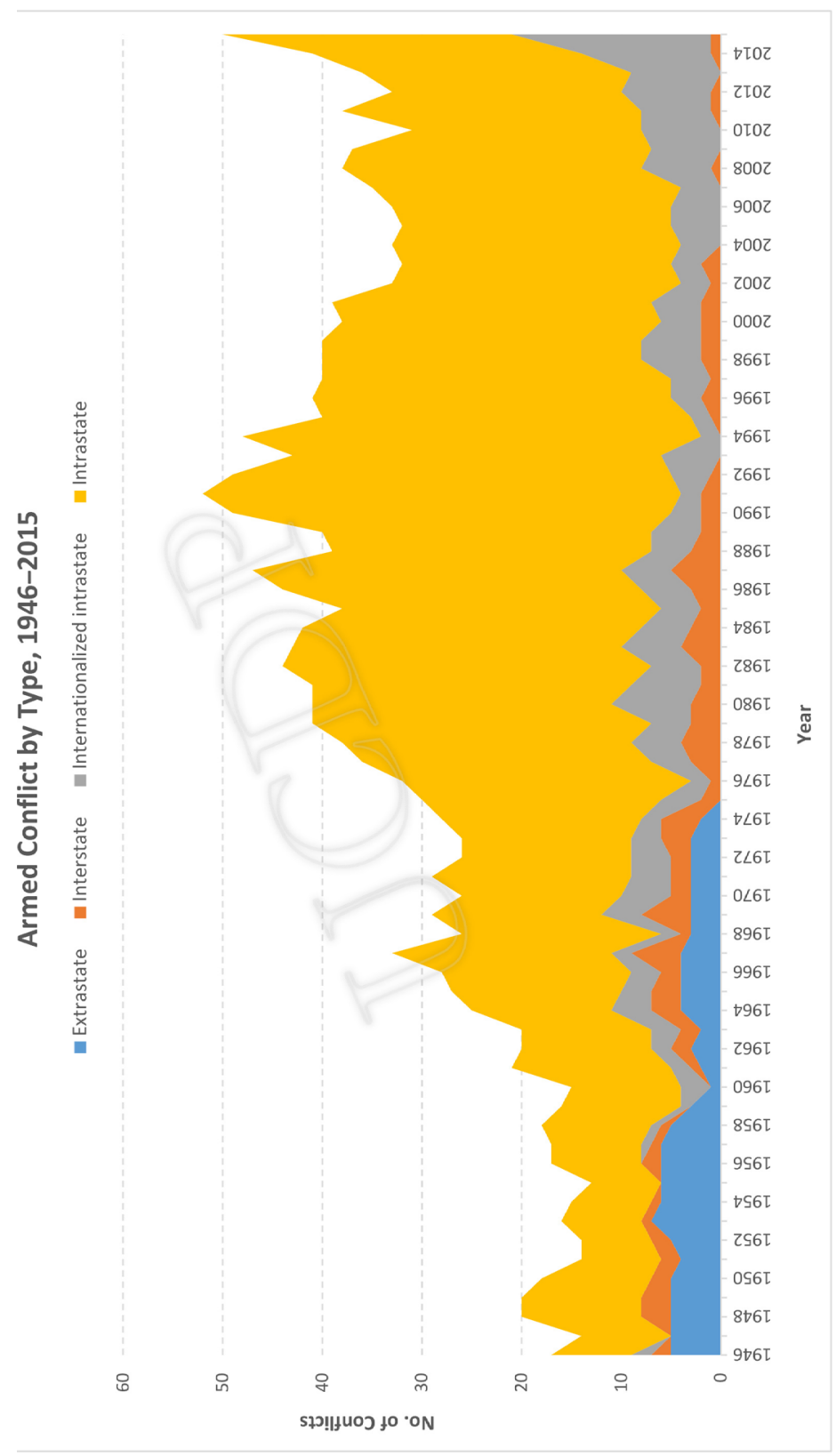


tions, also do not often meet the narrow criteria for war or disappear from the statistics (Northern Nigeria, parts of India in the Naxalite Red Belt), testifying to a 'spatial bias' that assumes that conflict violence is coterminous with the nation-state, and temporally limited. ${ }^{27}$ Finally, while some of this large-scale violence may represent the cumulative effect of inter-personal violence, much of it does not fit such notions of 'everyday violence' and a significant amount of it has political consequences linked to state fragility, organised crime, corruption, state violence and other factors that would logically be linked to the possible outbreak of wars and armed conflicts, yet do not form part of the repertoire of 'conflict knowledge'.

These omissions would not be important but for the way conflict trend data is used to create a narrative about our violent world. At the macro level, virtually everyone is familiar with some version of the graph in Figure 2, which purports to demonstrate the overall decline in violent conflicts since the end of the Cold War. The UCDP has published every year since 2000 some version of its summary data and trend analysis and, in addition to the relatively clear influence that earlier (COW) conflict data had on the 'democratic peace' argument (with its attendant policy implications), ${ }^{28}$ this data-driven expertise has generated the 'pacific states' literature, most prominently led by Steven Pinker and Joshua Goldstein, whose book and articles have a wide public reach, well beyond the scholarly sphere. ${ }^{29}$ As Nils Petter Gleditsch has pointed out, 'for the recent decline of war, Pinker, Goldstein, and others rely heavily on the UCDP/PRIO data'. ${ }^{30}$ Some scholars have also attributed the decline in armed conflict since the end of the Cold War to the intervention and effectiveness of UN peacekeeping, a message that resonated well (and was given a platform) within UN circles. $^{31}$

The conflict-data narrative that focused attention on particular forms of violent conflict also had an impact (albeit indirect) in how development assistance and post-conflict peacebuilding initiatives were framed. Until recently, most of the development assistance that was devoted to 'conflict-affected states' concentrated on the classical list of intra-state wars, even in situations with comparatively low levels of violence (such as in some African conflict zones, including Burundi, Liberia, etc.). Zones of relatively high violence (Central America) were excluded from programming support that focused on conflict and/or violence prevention and reduction, or post-conflict peacebuilding, even if the symptoms and pathologies of violence were linked organically to social conflicts and state fragility. There were some exceptions among development actors (notably USAID) and among recipient countries (Haiti), but generally major aid donors and multilateral organisations such as the OECD did not focus on 'high violence non-conflict' settings, and the UN Peacebuilding Commission focused almost entirely on intra-state or civil wars. The logic, while indirect and certainly not entirely attributable to 'conflict knowledge', was straightforward: war and armed conflicts as conventionally understood are the most important sources of local, regional and systemic insecurity, hence both policy and knowledge generation should focus on understanding and mitigating these threats. A globalised, network-focused and humansecurity oriented perspective would perhaps lead to different forms of knowledge generation, and a different policy focus. ${ }^{32}$ 


\section{Not all bodies count}

The widely used numerical threshold of one thousand battle-related deaths in one year shaped the early development of conflict knowledge and expertise in the COW projects; other scholars followed this lead for a considerable time, with often slightly scholastic debates about inclusion and exclusion. ${ }^{33}$ But conflict knowledge did not concern itself with dead bodies per se, since casualties - civilian or combatant - were considered a by-product, not a cause, of war, and hence little attention was devoted to this in the datasets, since the variable was not generally run in the analyses destined to produce scientific knowledge about war causation. The focus was instead on such things as geographic proximity, alliances and arms racing. ${ }^{34}$

Conflict scholars, however, were not oblivious to changes in the nature of war or in the way in which we understand it. By 2010, the COW project had broadened its datasets to include not only inter-state and extra-state wars, but what it called intra-state and non-state wars. ${ }^{35}$ Similarly, the UCDP had reduced the threshold for counting to twenty-five battle-related deaths per year and broadened its categories to include non-state conflict and 'one-sided violence' (attacks on civilians by governments and organised armed groups). Even more recent work has focused on geo-localised event data that counts individual incidents, in principle lowering the threshold even further. ${ }^{36}$ And researchers have also made use of death data to assess the lethality or intensity of recent wars, and whether or not battle deaths have been declining, or whether or not civilian casualties have been increasing as a proportion of total war deaths (which is not the same thing, since datasets did not calculate civilian casualties unless battle related) ${ }^{37}$ Body counts remained, however, a relatively marginal concern in the world of conflict knowledge. But the real problem lay not in what threshold criteria were used but in how the data was collected and what was included and excluded. There are three important problems with the way in which conflict knowledge treated the human costs of war, in ascending order of significance: systematic undercounting of violent deaths; near-total exclusion of excess mortality from the analysis; and an occlusion of non-somatic forms of violence that play a crucial role in the dynamics of conflict and conflict escalation.

First, the data gathered through media reports undercounts the direct battlerelated lethal impact of war. This undercounting is the product of reliance on limited sources, often media reports only in English, and of the quasi-systematic exclusion of civilian casualties that were not directly attributable to the war. It is widely acknowledged that media incident reporting - a form of 'passive surveillance' - is not comprehensive (especially when only English-language or non-local language sources are used), varies from conflict to conflict and tends to drop in quality as fighting increases or takes place in inaccessible areas. ${ }^{38}$ The media concentrate on urban events, in contrast to human rights organisations, for example, which capture large events, and interviews capture recent events (and individual incidents in non-urban areas). In Peru, for example, more than half of the 69,000 conflict deaths between 1980 and 2000 were not recorded in the press or other 
accounts. ${ }^{39}$ In Guatemala, the press reported no incidents of killings between September 1980 and September 1981, during the height of the urban counterinsurgency campaign (perhaps because seven journalists were killed in the period before the campaign). ${ }^{40}$ This would not be an issue for analytical purposes such as trend analysis or comparison if the under-reporting were consistent and unbiased, but there is no reason to make this assumption. More importantly, the numbers are not usually taken as (under-)estimates but as actual death counts, and caveats are buried in footnotes. Even more problematic is the assumption that media reports capture systematically and in an unbiased way the identity of the perpetrators and their motivations (criminal versus political violence, for example), since this depends on the judgement of the journalist before the input of the expert coder.

The controversy over war deaths in Iraq illustrates well how serious and systematic undercounting from passive reporting can be. For the period 2003-15 the Iraqi Body Count documented between 144,384 and 166,085 civilian deaths from conflict-related violence and a total of 220,000 deaths including combatants, ${ }^{41}$ while household surveys estimated even higher figures (see below). The UCDP data, however, records only 53,361 deaths over this period - around one third of the total. ${ }^{42}$ Aside from reliance on media reports, UCDP data relied on a problematic counting rule: it required that deaths be counted as 'conflict victims' only in situations in which a perpetrator was identified. ${ }^{43}$ This is ethically troubling: you deserve to be counted as a war victim only if Western analysts with their database coding rules can determine who killed you! The UCDP does acknowledge that battle-related deaths represented only a proportion of the violence in Iraq, but, for example, morgue data that did not include information about perpetrators was nonetheless excluded, even though up to a hundred bodies per day often turned up in Baghdad. If one zooms in on one year (2006) and compares UCDP data with UN sources (which was passive surveillance based on information from morgues, hospitals and municipal authorities across Iraq), the difference is an entire order of magnitude: from 3,500 to 34,000 violent deaths. Although the larger UN figure includes all types of violence, including conflict deaths, attacks on civilians, homicides, criminality and domestic violence, it was clear to analysts that many of the different forms of violence in war-torn Iraq were related. Using the UCDP data as a way to grasp the intensity, dynamics or human costs of the war in such a situation would be so misleading as to constitute wilful blindness. ${ }^{44}$

Second, the narrow focus on battle-related deaths, sometimes of combatants only, sometimes of combatants and civilians, obscures the much greater burden of indirect deaths or excess mortality that arises from violent conflict. To put it graphically, an armed group may sweep through a village, kill several inhabitants, burn homes and destroy infrastructure. The population is thus deprived of access to basic needs - food, water, basic healthcare - and, whether they remain in place or flee towards displacement or refugee camps, often high numbers of the young, old and otherwise vulnerable die in the subsequent weeks and months. This 'excess mortality' (excess to the non-conflict scenario) can be counted precisely through population surveys, verbal autopsies and other such techniques. ${ }^{45}$ In several recent conflicts, including in South Sudan, Darfur, Burundi, Iraq and 


\section{Keith Krause}

Liberia, indirect deaths have represented between four and ten times the number of direct victims of violence. ${ }^{46}$ In the DRC, perhaps the most dramatic recent case, a reported 3.3 million people died between 1998 and $2002 .{ }^{47}$ While that figure may be too high, only a relatively small percentage (perhaps no more than 10 per cent) of the victims died violently. These deaths are still narrow 'physical harm' with lethal consequences; what is critical is that they do not rest on a narrow concept of agency: identifiable perpetrators, acts (use of force, threats and displays of force) causing immediate harm and individual victims. Body counts of violent deaths from passive reporting completely occlude the lethal consequences of these diffuse actions by corporate or collective agents such as the state or armed militias.

The final problem, leaving thresholds and counting rules aside, concerns the way in which a focus on violent deaths as a trigger for determining the existence (or not) of a conflict means that wars and conflicts are deemed to begin only when a certain number of dead bodies appear. Yet violence is also an outcome of a conflict, and when conflict expertise focuses on certain thresholds of violence it obscures other forms of prior, systematic and non-lethal forms of 'violence as violation' that are almost always an important antecedent element in the processes and mechanisms of conflict escalation. ${ }^{48}$ As Gleditsch et al. acknowledge, aggregate data 'provide no information on conflict dynamics or events within conflicts over time ... This often led to a notable disjuncture between theories of conflict that are increasingly specific in highlighting micromechanisms and data a relatively high level of aggregation. ${ }^{49}$ Even if this is somewhat rectified by the use of more finegrained event data on individual incidents, the focus on body counts still excludes non-physical forms of violence and repression, including 'personal integrity rights ... concerned with individual survival and security, such as freedom from torture, 'disappearance', imprisonment, extrajudicial execution, and mass killing'. ${ }^{50}$

These forms of violence as violation frequently implicate the state and its agents, or involve forms of sexual and gender-based violence, yet such violence forms are almost entirely absent from conflict knowledge unless and until an opposition organises, declares itself opposed to the state, takes up arms and suffers casualties, at which point its deaths register as conflict knowledge. The result, as Christian Davenport notes, is that 'researchers have paid far more attention to the evils done against governments (and citizens) by dissidents, rebels, and terrorists than to the evils done by presidents, the police, military, secret service, national guards, and death squads against those within their territorial jurisdiction'. ${ }^{51}$ The politics of violent death data have, with a few notable exceptions such as Iraq, the DRC or Darfur, a significant pro-state or pro-government bias. These exceptions were usually the result of non-governmental or humanitarian engagement of researchers in order to shine a spotlight on a particular conflict, underlying again the politics of selective (even if well intended) attention. In some cases (notably in one Iraq survey, but also in the DRC), numbers appear to have been inflated, or at least selected for dramatic effect, potentially to the detriment of a more nuanced picture.

The 2010-11 Jasmine revolution in Tunisia is an excellent example of the prostate bias, catalysed by the on-going and pervasive corruption and repression of President Ben Ali's regime. The Tunisian case is representative of any authoritar- 
ian state that violates its citizens without (often or systematically) killing them. Syria, for example, remained strongly authoritarian with relatively low levels of overt violence since the large-scale massacre of Islamists in Hama under Hafez al Assad in 1982, which resulted in between ten and forty thousand citizens killed by the state. ${ }^{52}$ There were relatively few politically related violent deaths in Syria in the years leading up to 2011, making the explosion of violence in 2011-15 seem as something externally generated and motivated, rather than a product of the domestic context. The state-centric bias in conflict expertise and analysis is not only a function of the way in which data is collected and used; it is also based on a mistaken belief or assumption that "illegitimate" and "legitimate" forms of conflict, coercion, and expropriation stem from essentially different processes: processes of change and disorder on one side, and processes of integration and control on the other'; they are, rather, unified in one dynamic and process..$^{53}$

\section{Ignorant expertise, policy practice and counting (mostly missing) bodies}

Conflict knowledge about body counts produced by international relations and conflict studies scholars is not the most important way in which such expertise is mobilised in the sphere of global public policy. Other than the few examples noted above (World Bank, OECD, democratic peace), there is little evidence that any of this work - despite its increasing sophistication and empirical detail - has an impact on, or contact with, policy and practice. But, working in parallel, researchers from the public health, demographic, humanitarian and human rights (transitional justice) communities also generate data and analysis about dead bodies, often with more rigorous techniques and methods. This work, usually focused on individual cases of conflict, has as its main motivation to account for the victims of conflict, mass violence and genocide so as to provide reliable estimates of the human costs of war and violence in order to promote accountability and transitional justice (truth and reconciliation) and, secondarily, to establish thresholds for the delivery of humanitarian relief and assistance. It too is not without controversy, but the contrasts between these forms of conflict knowledge (and their findings) and those of international relations and conflict studies are striking. Here I want to highlight the public policy implications of conflict-death expertise in two related realms, which in some circumstances have been of extreme political salience, in places such as Darfur, Iraq, Guatemala or Timor Leste. The two realms are those of humanitarian relief and the way in which war-related deaths are used to determine thresholds for 'emergencies' that trigger large-scale humanitarian relief efforts, and post-conflict and transitional justice efforts to bring the perpetrators of mass killings to account.

The humanitarian industry - which addresses tragedies ranging from famine and natural disasters to war-displaced populations - doubtless provides shelter, safety and succour for millions of people each year. But, until recently, resources followed headlines, high-profile events or even media campaigns by major NGOs, rather than an assessment of critical needs. Within the humanitarian community, 


\section{Keith Krause}

this led to a call for harmonised standards - based on systematic and conflictexpert assessments - to determine what was and was not a real humanitarian catastrophe. ${ }^{54}$ The result took the form of attempts to use a body count - a mortality rate - to establish either a universal or a relative threshold that would be one part of the determination for providing emergency relief and taking action. The absolute rate was 'usually taken as a crude mortality rate of 1 per 10000 per day, or as an underfive mortality rate of 2 per 10000 per day'. ${ }^{55}$ A more relative standard is deployed in the Sphere project, which advocated relief efforts to 'maintain the crude mortality rate (CMR) and under-five mortality rate (U5MR) at, or reduce to, less than double the baseline rate documented for the population prior to the disaster' ${ }^{56}$ It is worth doing the maths to see what this means: in a conflict zone with a population of one million, this would mean an absolute rate of one hundred deaths per day, or around three thousand per month!

The standard was one thing; the question of how to assess it was altogether another. It was assessed ideally through surveys conducted in camps of refugees and displaced persons, where mortality data was directly obtained from camps themselves, simply tallying the number of persons in the camp and the number of deaths over time. But surveys even under such conditions are fraught with all sorts of methodological and political pitfalls, given the uncertainty surrounding camp entry and exit and the relevant population. The best cases were also not the most important ones, since a humanitarian emergency could (and often did) unfold well outside of camps, and long before aid workers appeared on the scene. The determination of whether or not the threshold had been crossed in these situations then depends on the deployment of complex survey techniques (including verbal autopsies, historical population estimates, different random sampling methods, etc.) to measure mortality. And again, one's body 'counts' only if someone is there to count it - or at least estimate its absence. These various forms of expert knowledge suffer from all sorts of serious shortcomings - a clear form of ignorant expertise although they represent one part of the foundation for determinations to allocate resources that can have enormous human consequences.

Transitional and post-conflict justice has pursued two intertwined goals in its work on body counts: to assess the scope and scale of mass killing - a form of bearing witness to silent and invisible deaths - and to contribute practically to the pursuit of justice. Sophisticated statistical, demographic or survey techniques have been used to establish estimates of the invisible and uncounted victims in places such as Cambodia, Peru, Iraq, Guatemala, Timor Leste, Kosovo, Colombia and Syria. ${ }^{57}$ All are subject to great uncertainty, a form of ignorant expertise, and I will focus on one widely used technique - multiple systems estimation (MSE) - that has specifically been invoked in post-conflict justice deliberations (in Guatemala and the former Yugoslavia).

MSE is a technique originally used to estimate wildlife populations (say, fish in a pond) by drawing repeated random samples from the population and uniquely identifying them (tagging). The number of multiple catches of a single individual identifies the overlap in the samples and can be used to estimate the 'missing' population that is not captured in any sample. When applied to body counts, the 
requirement is that there are lists of victims, independently and randomly gathered, that can be suitably matched (names, time and place of death) in order to determine the overlap and hence estimate the total number of victims that are not accounted for in any list. ${ }^{58}$ Many recent conflicts have had such lists of the dead collected by NGOs, faith groups or international organisations, based on eyewitness accounts, graveyard and mortuary records and other sources, and have had MSE analyses performed. ${ }^{59}$ In Guatemala, the research concluded that approximately 200,000 people had been killed between 1960 and 1996, that the state's security forces were responsible for the overwhelming proportion of these deaths and, most importantly, that indigenous peoples were vastly over-represented in the deaths and therefore that the killings by state forces could be qualified as genocidal. ${ }^{60} \mathrm{~A}$ Guatemalan court subsequently found former President Gen. Efraín Ríos Montt guilty of genocide, and although the ruling was later overturned on a technicality, its symbolic importance remained. ${ }^{61}$

How, in such a context, is the expertise 'ignorant?' In the simplest sense, it is ignorant because the figures arrived at are estimates, not accounts of individual deaths with names and other details. In Guatemala, for example, the extrapolated number of 200,000 deaths was based on testimonies of approximately 13,000 people in three databases that covered about 42,000 'known' victims, leading through matching of other sources to an estimate of 132,000 deaths. ${ }^{62}$ Not surprisingly, debate continues around these figures and conservative estimates based on more 'accurate' counts (that is, of actual named victims) propose an estimate of $37,000 \mathrm{dead}$. The difference is rather significant and turns on whether or not one can have faith in statistical techniques to provide a better picture of the reality of violent death in Guatemala than seemingly more tangible lists of named victims, dates and places.

From a more formal point of view, the key assumptions of MSE are seldom met, and in particular individual records are usually incomplete and the randomness and independence of the lists is difficult if not impossible to guarantee. Data collection by NGOs and other groups tracks networks (for example, members of a particular church), and socially connected individuals are more likely to be counted, affecting the overall estimates. In other contexts such as Iraq, where household surveys have been widely used to estimate conflict deaths, the final estimates are derived from a maximum of two thousand households surveyed for the entire country. Without diving into the details, the sampling technique may also have problems, this time of a geographic nature, since use of a 'random walk' method for identifying and sampling households to survey off main streets may lead to oversampling near major intersections and roads. In the case of deaths from roadside bombs in Iraq this appeared to be a significant source of potential bias and over-estimation in some surveys. ${ }^{63}$ The estimates for the total number of deaths in Iraq range wildly (up to 600,000 between 2003 and 2006) and are still subject to on-going debate, although the consensus seems to be that around 150,000 people died violently as a result of the fighting between 2003 and 2006, which is still considerably higher than the figures from individual accounting sources such as the Iraqi Body Count (around 70,000) and excludes any indirect deaths or excess mor- 
tality. ${ }^{64}$ The point is not that this ignorant expertise regarding body counts in cases such as Guatemala, Iraq and elsewhere is irremediably flawed, for it is likely better than most alternatives, but, rather, that the uncertainties and assumptions are washed out when such expertise enters the policy sphere that requires epistemic certainty.

\section{Conclusions: linearity and singularity in conflict knowledge}

When one moves from counting and classifying to the more complex task of analysing and understanding, the production of ignorant conflict expertise becomes a potent tool for designing and directing policy and programmatic interventions. In concluding reflections I want to draw attention to two linked fallacies (or oversimplifications) concerning the linearity and singularity of conflict processes that appear on both the scholarly and policy-relevant sides of the fence and that exert a pernicious effect on how international conflict interventions are conceived of and designed. While it is easy to show how these operate in both policy and research spheres, it is much more difficult to demonstrate how conflict scholarship and policy analysis feed off one another in this domain.

The aggregate data in conflict databases is usually analysed with linear causal or quasi-causal models that are designed to isolate variables that account for the greatest degree of variation in outcomes, or are associated with the probability of war outbreak. ${ }^{65}$ As the proponents of the COW project put it, their ambition was to develop 'an integrated and coherent theory of war causation' based on a grasp of the general factors that led to war. ${ }^{66}$ While diving into the details of statistical tests is not the purpose of this chapter, many of the models tested suffer from endogeneity and collinearity problems and ignore both history and time (in the sense that events are not independent, and unfold through the interaction of complex processes that are path dependent).$^{67}$ But the problem here is not just one of inadequate data, insufficiently fine distinctions or underspecified models. Rather, the entire idea that conflict and violence would unfold along a linear path is based on widespread acceptance of what Andrew Abbott has called 'general linear reality' models as a way of describing how society works that results from 'treating linear models as representations of the actual social world' ${ }^{68}$

Here the link between scholarship and practice can be at least asserted, if not proved: if scholars' dominant models of conflict analysis in international relations rest upon 'general linear reality models', then it is no surprise that in the more policy- or practice-oriented world a sort of expert mimicry leads analysts to adopt the language of root causes and linear causation to frame their prescriptions and to draw upon what limited evidence they can find to support such claims. Practitioners in the policy world tend to operate with tools drawn from new public management techniques (stages of conflict, conflict-actor mapping) and simplified accounts of motivations and means that produce flat and caricatured accounts of contemporary conflicts to guide practical programming, and that mirror several of the analytic and empirical weaknesses of international relations conflict scholars. Conflict is usually conceived as unfolding on a linear path with clear stages and 
direction, actors are considered to be unitary and uni-motivated and the emphasis is placed on the agency of actors (needs, fears, power relations, attitudes etc.), rather than on any of the larger structural factors that might play a role (inequality, governance etc.). ${ }^{6}$

In both cases, scholars and analysts engage in turning what are essentially social facts about the nature of actors and the causes of conflict and violence into brute facts that have an elevated 'expert' status, with the attendant claims to power/ knowledge. None of this means that there are not mechanisms and processes in the social world that link particular antecedent conditions with certain (violent) outcomes. There is some connection between a Tunisian street vendor's death and the widespread violence in North Africa today, or between the assassination of Archduke Franz Ferdinand and the First World War. But this claim is very different from the belief in a 'general linear reality' model, which hews to a much stronger version of causal analysis applicable to a wide range of conflict processes.

The 'singularity fallacy' presumes that each form of violence, within and between different violent spaces, is self-contained in time and space and follows particular pathways that have a discernible beginning and end. Each violent episode is thus independent, and history - which includes guiding metaphors, lessons learnt, sequence and recurrence - does not matter. Each violent actor has one set of motives (and identity) and different forms of violence are layered on top of each other (much like a millefeuille pastry), with little contact between the different levels. Programmatic or policy 'treatments' can be thus designed to focus on one or the other of these levels, without too much regard to how different forms may fit together in time and space. In policy terms the result is the stove-piping of different programmatic responses: 'post-conflict' programmes dealing with such things as the disarmament and demobilisation of ex-combatants are separate from, for example, those designed to address sexual and gender-based violence (SGBV) (even in conflict zones), and the latter are deployed in the absence of specific links to the broader peacebuilding context. But, as Maria Eriksson Baaz and Maria Stern point out, 'the specific, often exclusive, focus on sexual violence ... hampers our understanding of the relationship between sexual violence and other (supposedly) "ungendered" violence.... These forms of violence are, to a large extent, manifestations of the same systemic failures and mechanisms as those contributing to SGBV.'70

Yet contemporary conflicts do not fit this model, with fluid and changing motivations and blurred lines between economic and material - as opposed to political or ideational - motivations. Examples abound, from the warlords of West Africa, to the vigilantes and political gangs of Nigeria, to the armed horsemen of the janjaweed, to the rent-seeking and criminal behaviour of previously ideologically driven groups such as the FARC in Colombia or UNITA in Angola. As Rafaâ Tabib highlights in the Libyan context, 'criminal accumulation, land grabs, and protection rackets' are major factors driving

the actions of tribal militias and jihadist groups, and the ... fighting that has blighted Libya. While conventional representations of Libya's post-revolutionary period 


\section{Keith Krause}

dwell on the political battle between Islamists and secular forces ... the cause of the country's increasing levels of armed violence can be found in the absence of a functional state and the fragmentation of local, tribal, ethnic and ideological forces, which together make the violent acquisition of material resources essential to group survival. ${ }^{71}$

Or in Pakistan, one can chart more than twenty separate 'dyads' or 'triads' of conflict, the main actors being the state, the Lashkar-e-Islam and the Taliban (with some different factions in both of these). These overlapping conflicts are intensely violent, generating two to three thousand deaths per year, and in addition they are linked with such things as high levels of urban political violence in cities such as Karachi. These are not different 'forms' of violence; they are part of a complex and violent matrix that produces at least five thousand dead bodies a year. ${ }^{72}$

Overall, I have tried to trace the ways in which scholarly analysis of war and conflict has been mimicked and mirrored in the creation of particular forms of 'expertise' and expert knowledge that shape practical policy and programming to deal with conflicts. The picture is by necessity tentative and somewhat caricatured, and it is evident that there is much scholarship (and perhaps some practice) that does not fall into all of the pathologies I have outlined above. In addition, the particular pathologies that affect scholarship are not always linked to policy and programming, or are linked in indirect and complex ways. But on both the scholarly and the policy side, the politics and scholarship of body counts reflects a variety of forms of ignorant expertise. Although idiographic sociological, historical, ethnographic, anthropological and thickly descriptive accounts of particular violent confrontations are readily available for any contemporary conflict, these are seldom linked to the macro-level, scientific and generalisable ambitions of both international relations scholarship and policy relevant expertise. Ignorant expertise thus rules the day.

\section{Notes}

1 The formula varies, but most common is savoir pour prévoir, afin de pouvoir.

2 For recent exceptions see J. Auchter, 'Paying Attention to Dead Bodies: The Future of Security Studies?' Journal of Global Security Studies 1:1 (2016), 36-50; T. Seybolt et al. (eds), Counting Civilian Casualties (Oxford, Oxford University Press, 2013); R. Read and R. MacGinty, 'The Politics of Coding Violence: Exploring the Ontologies of Security Incident Databases', unpublished paper, 2015.

3 A. des Forges, Leave None to Tell the Story: Genocide in Rwanda (New York, Human Rights Watch, 1999); J. H. Heuveline, 'Between One and Three Million: Towards the Demographic Reconstruction of a Decade of Cambodian History (1970-1979)', Population Studies 52 (1998), 49-65; B. Kiernan, 'The Demography of Genocide in Southeast Asia: The Death Tolls in Cambodia, 1975-79, and East Timor, 1975-80', Critical Asian Studies 35:4 (2003), 585-97; E. Tabeau and J. Zwierzchowski, 'A Review of Estimation Methods for Victims of the Bosnian War and the Khmer Rouge Regime', in Seybolt et al. (eds), Counting Civilian Casualties, pp. 213-43. 
4 I. Vonèche Cardia, 'The International Committee of the Red Cross: Identifying the Dead and Tracing Missing Persons - a Historical Perspective', in M. A. Pérouse de Montclos, E. Minor and S. Sinha (eds), Violence, Statistics, and the Politics of Accounting for the Dead (Switzerland, Springer, 2016), pp. 71-86.

5 This can be viewed at https://en.wikipedia.org/wiki/Charles_Joseph_Minard\#/ media/File:Minard.png.

6 A. Zamoyski, Moscow 1812: Napoleon's Fatal March (London, Harper Collins, 2004).

7 M. Vinovskis, 'Have Social Historians Lost the Civil War? Some Preliminary Demographic Speculations', The Journal of American History 76:1 (1989), 34-58. Probably the first systematic attempt was W. F. Fox, Regimental Losses in the American Civil War (Albany, Albany Publishing Company, 1889), which calculated losses at the regimental, not individual, level.

8 The more general use of statistics in administration of the modern state is dealt with comprehensively by A. Desrosières, The Politics of Large Numbers: A History of Statistical Reasoning (Cambridge, MA, Harvard University Press, 1998).

9 K. Varley, 'Remembering the Franco-Prussian War Dead: Setting Precedents for the First World War', History of Modern France at War, https://francehistory. wordpress.com/2013/11/05/remembering-the-franco-prussian-war-dead-settingprecedents-for-the-first-world-war/ (accessed 14 December 2016). See also K. Varley, Under the Shadow of Defeat: The War of 1870-1871 in French Memory (London, Palgrave, 2008). The Treaty of Frankfurt required both France and Germany to respect and maintain war graves on their soil.

10 These deaths are called by demographers excess mortality. See G. Parker, The Thirty Years' War, 2nd edn (New York, Routledge, 1997), p. 188. Korea figure from B. Lacina, N. P. Gleditsch and B. Russett, 'The Declining Risk of Death in Battle', International Studies Quarterly 50:3 (2006), 675; DRC calculation from B. Coghlan et al., 'Mortality in the Democratic Republic of Congo: A Nationwide Survey', The Lancet 367:9504 (January, 2006), 44-51; B. Coghlan et al., Mortality in the Democratic Republic of Congo: An Ongoing Crisis (New York, International Rescue Committee, 2008).

11 C. Hirschman, S. Preston and V. Manh Loi, 'Vietnamese Casualties during the American War: A New Estimate', Population and Development Review 21:4 (1995), 783-812.

12 M. Norris, 'Military Censorship and the Body Count in the Persian Gulf War', Cultural Critique, 19 (Autumn, 1991), 223-45.

13 E. Tabeau and J. Bijak, 'War-Related Deaths in the 1992-1995 Armed Conflicts in Bosnia and Herzegovina: A Critique of Previous Estimates and Recent Results', European Journal of Population/Revue européenne de Démographie 21:2-3 (2005), $187-215$.

14 N. P. Gleditsch, K. Skrede, N. W. Metternich and A. Ruggeri, 'Data and Progress in Peace and Conflict Research', Journal of Peace Research 51:2 (2013), 301-14; J. Vasquez and M. Henehan, The Scientific Study of Peace and War (Lexington, Lexington Books, 1999); D. O. Wilkinson, Deadly Quarrels: Lewis F. Richardson and the Statistical Study of War (Berkeley, University of California Press, 1980). 


\section{Keith Krause}

15 World Bank, World Development Report (Washington, DC, World Bank, 2011), p. 51.

16 The most widely proposed indicators for this are homicide rates and conflict death rates (per 100,000 or absolute numbers).

17 See, for a prominent example, OECD, States of Fragility 2015: Meeting Post-2015 Ambitions (Paris, OECD Publishing, 2015), http://www.oecd.org/dac/governancepeace/conflictfragilityandresilience/rf.htm (accessed 14 December 2016), which cites Uppsala figures throughout.

18 Wilkinson, Deadly Quarrels, pp. 10-11. By contrast, Quincy Wright's definition of war as 'the legal condition which equally permits two or more hostile groups to carry on a conflict by armed force' was much narrower, focusing on coherent groups and legal status, thus excluding most sub-state violence. Q. Wright, A Study of War, abridged edition (Chicago, University of Chicago Press, 1942), p. 7.

19 L. Richardson, cited in Wilkinson, Deadly Quarrels, p. 11.

20 Richardson's ultimate list included both so-called inter-state and civil wars, but excluded 'deadly quarrels' that did not involve states or state-like entities. J. David Singer and Melvin Small, who argued that inter-state war ought to be the proper object of study in international relations, criticised him for even this choice, but later abandoned this position. See D. Singer and M. Small, Resort to Arms: International and Civil War,1816-1980 (Beverly Hills, Sage, 1982).

21 M. J. Boyle, 'Progress and Pitfalls in the Study of Political Violence', Terrorism and Political Violence 24:4 (2012), 527-43, 529. As Douglas Lemke and David Cunningham have also argued, 'the similarity in causes ... make us wonder whether the causes of civil wars ... might also be the causes of a wider variety of sub-state violence and disruptions. Could the causes of civil wars also be the causes of riots, demonstrations, purges, and wars among disparate nongovernmental societal segments?' D. Cunningham and D. Lemke, 'Beyond Civil War: A Quantitative Analysis of Sub-state Violence', unpublished paper, American Political Science Association Annual Conference, 2011, p. 1.

22 For example, in those studies that focused on variables such as trade, borders, form of government, military spending etc., the 'stateness' of the main actors was critical.

23 Uppsala Conflict Data Program, '2013 Armed Conflict Update: Two of the Five War Fatalities Occurred in Syria', Uppsala Conflict Data Program (2014), https:// uppsalaconflictdataprogram.wordpress.com/2014/06/18/2013-armed-conflictupdate-two-out-of-five-war-fatalities-occurred-in-syria/ (accessed 14 December 2016).

24 L. Themnér and P. Wallensteen, 'Armed Conflicts, 1946-2013', Journal of Peace Research 51:4 (2014), 541-554. The figures for total battle deaths were 38,000, of which around 14,700 (40\%) were in Syria.

25 M. Sarkees and F. Wayman, Resort to War: 1816-2007 (Washington, DC, CQ Press, 2010).

26 On Yemen see Small Arms Survey, Under Pressure: Social Violence over Land and Water in Yemen (Geneva, Small Arms Survey, 2010). 
27 See F. B. Adamson, 'Spaces of Global Security: Beyond Methodological Nationalism', Journal of Global Security Studies 1:1 (2016), 19-35. On the Naxalites see A. Sinha, 'The Naxalite Insurgency in India', 14 November 2012, http://carnegieendowment.org/2012/11/13/naxalite-insurgency-in-indiaevent-3862 (accessed 14 December 2016).

28 For its influence on recent American foreign policy see D. Brinkley, 'Democratic Enlargement: The Clinton Doctrine', Foreign Policy 106 (Spring 1997), 111-27, and B. Russett, 'Bushwhacking the Democratic Peace', International Studies Perspectives 6:4 (2005), 395-408.

29 S. Pinker, The Better Angels of Our Nature: The Decline of Violence in History and its Causes (London, Penguin, 2011); S. Pinker and A. Mack, 'The World Is not Falling Apart: Never Mind the Headlines', Slate 22 (December 2014), http:// www.slate.com/articles/news_and_politics/foreigners/2014/12/the_world_is_not_ falling_apart_the_trend_lines_reveal_an_increasingly_peaceful.html; J. Goldstein, Winning the War on War (New York, Penguin, 2011). Pinker takes a much longer historical perspective, but the contemporary data used is the same.

30 N. P. Gleditsch et al., 'The Forum: The Decline of War', International Studies Review 15:3 (2013), 396-419, 397.

31 Human Security Centre, Human Security Report 2005: War and Peace in the 21st Century (Oxford, Oxford University Press, 2005), pp. 153-5.

32 Arguably, the attention given to tackling violent extremism does reflect this shift somewhat, but it is not divorced from conventional conflict knowledge narratives.

33 The Falklands War, for example, resulted in fewer than a thousand battle deaths and hence was not included in the databases. On a slightly different note, within the 'democratic peace' debate US mining of Nicaraguan harbours was excluded by some scholars since it was 'covert' (without formal authorisation), despite its having been recognised by the ICJ as an act of war. Inclusion would have spoilt the early record of no democracies having gone to war with each other!

34 P. Weitsman, 'Alliances and War', The International Studies Encyclopedia 1 (2010), 82-98; T. J. Rider, M. G. Findley and P. F. Diehl. 'Just part of the game? Arms Races, Rivalry, and War', Journal of Peace Research 48:1 (2011), 85-100.

35 M. Sarkees and F. Wayman, Resort to War, Washington, CQ Press, 2010.

36 These include the Armed Conflict Location and Event Data (ACLED) and UCDP Georeferenced Event Datasets (UCDP GED) (C. Raleigh,et al., 'Introducing ACLED: An Armed Conflict Location and event Dataset Special Data Feature', Journal of Peace Research 47:5 (2010), 651-60.). For a critique of this see Read and MacGinty, The Politics of Coding.

37 See Lacina et al., 'The Declining Risk of Death in Battle', which critiques M. R. Sarkees, F. W. Wayman and J. D. Singer, 'Inter-State, Intra-State, and Extra-State Wars: A Comprehensive Look at Their Distribution over Time, 1816-1997', International Studies Quarterly 47:1 (2003), 49-70, who argued for 'the risk of death in battle trending neither up nor down since the date of Napoleon's exile'. See also M. Spagat et al., 'Estimating War Deaths an Arena of Contestation', Journal of Conflict Resolution 53:6 (2009), 934-50; Z. Obermeyer, C. J. L. Murray 


\section{Keith Krause}

and E. Gakidou, 'Fifty Years of Violent War Deaths from Vietnam to Bosnia: Analysis of Data from the World Health Survey Programme', British Medical Journal 336:7659 (19 June 2008), 1482-6.

38 C. Davenport and P. Ball, 'Views to a Kill: Exploring the Implications of Source Selection in the Case of Guatemalan State Terror, 1977-1995', Journal of Conflict Resolution 46:3 (2002), 427-50; S. Chojnacki et al., 'Event Data on Armed Conflict and Security: New Perspectives, Old Challenges, and Some Solutions', International Interactions 38:4 (2012), 382-401, 386.

39 P. Ball et al., How Many Peruvians Have Died? An Estimate of the Total Number of Victims Killed or Disappeared in the Armed Internal Conflict between 1980 and 2000 (Washington, DC, American Association for the Advancement of Science, 2003).

40 D. Nelson, 'Bonesetting: The Algebra of Genocide', Journal of Genocide Research 18:2-3 (2016), 171-87.

41 'Iraq Body Count', n.d., https://www.iraqbodycount.org/ (accessed 15 October 2015). I will return below to household survey figures for the Iraq War.

42 The sum of 'war and minor conflict', 'non-state conflict', and 'one-sided violence' categories. See 'Recorded Fatalities in UCDP Organized Violence 1989-2015', n.d., http://www.ucdp.uu.se/gpdatabase/gpcountry.php?id=77\&regionSelect=10Middle_East\#. (accessed 25 October 2015).

43 See G. Wischnath and N. P. Gleditsch, 'Battle Deaths - Comparing the UCDP and PRIO Data', unpublished paper, Centre for the Study of Civil War, Peace Research Institute Oslo (PRIO), 2011.

44 P. Green and T. Ward, 'The Transformation of Violence in Iraq', British Journal of Criminology, 49 (2009), 609-27.

45 P. Wise, 'The Epidemiologic Challenge to the Conduct of Just War: Confronting Indirect Civilian Casualties of War', Dodalus 146:1 (2017), 139-54.

46 For a range of estimates for several recent conflicts, see Geneva Declaration Secretariat, Global Burden of Armed Violence (Geneva: Geneva Declaration Secretariat, 2008), pp. 40, 46-7. Parenthetically, pre-1990 conflicts in COW and other data sets often conflate the two, providing strange comparisons. For example, 'the Korean War - an interstate conflict - is listed by COW with 909,833 total deaths, which is a plausible accounting of combat deaths among only military personnel. COW records 1.3 million "state deaths" in the civil war in the south of Sudan from 1983 to 1997, a reasonable estimate of all deaths that war caused due to massive famine and disease among civilians. Comparing those two figures would characterise the Korean War as the smaller conflict when, in fact, it was much larger. Five to six million people are believed to have starved to death during the Korean War; combat deaths in the Sudan through 1997 were less than 100,000' (Lacina et al., 'The Declining Risk', 675).

47 There is controversy over these figures, with estimates for the later (less violent) period of 2001-7 ranging from 2.8 million excess deaths to 'only' 860,000. See Human Security Research Group, Human Security Report 2009/2010: The Causes of Peace and the Shrinking Costs of War (Oxford, Oxford University Press, 2011), pp. 123-31. 
48 See V. Bufacchi, 'Two Concepts of Violence', Political Studies Revie, 3 (2005), 193-204.

49 Gleditsch et al., 'The Forum: The Decline of War', 305.

50 C. Davenport, 'State Repression and Political Order', Annual Review of Political Science 10 (2007): 2.

51 Ibid., 1. With respect to sexual and gender-based violence and its links to war and armed conflict see D. K. Cohen, 'Explaining Rape during Civil War: CrossNational Evidence (1980-2009)', American Political Science Review 107:3 (2013), 461-77.

52 R. Fisk, Pity the Nation (London, Touchstone, 1990), pp. 181-7.

53 C. Tilly, Big Structures, Large Processes, Huge Comparisons (New York, Russell Sage Foundation, 1984), p. 12.

54 M. Buchanan-Smith, How the Sphere Project Came into Being: A Case Study of Policy-Making in the Humanitarian Aid Sector and the Relative Influence of Research (London, Overseas Development Institute, 2003).

55 For details see F. Checchi and L. Roberts, 'Interpreting and Using Mortality Data in Humanitarian Emergencies', Humanitarian Practice Network 52 (2005), 1-38; and F. Checchi and L. Roberts, 'Documenting Mortality in Crises: What Keeps Us from Doing Better?' PLoS Med 5:7 (2008), 1025-32.

56 The Sphere Project, The Sphere Handbook: Humanitarian Charter and Minimum Standards in Humanitarian Response (Geneva, The Sphere Project, 2011), p. 292.

57 On the use of surveys, see J. Asher et al., 'Using Surveys to Estimate Casualties Post-Conflict', in Seybolt et al. (eds), Counting Civilian Casualties (Oxford, Oxford University Press, 2013), pp. 97-122 (2008); also Tabeau and Zwierzchowski, 'A Review of Estimation Methods'.

58 For a somewhat technical overview see K. Lum, M. Price and D. Banks, 'Applications of Multiple Systems Estimation in Human Rights Research', The American Statistician 67:4 (2013), 191-200; and several cases, J. Asher, D. Banks and F. Scheuren (eds), Statistical Methods for Human Rights (London, Springer, 2008).

59 On Peru, see Ball et al., How Many Peruvians Have Died?; for Timor-Leste see R. Silva and P. Ball, 'The Profile of Human Rights Violations in Timor-Leste, 1974-1999: A Report by the Benetech Human Rights Data Analysis Group to the Commission on Reception, Truth and Reconciliation of Timor-Leste' (2006), https:/hrdag.org/content/timorleste/Benetech-Report-to-CAVR.pdf (accessed 14 December 2016); on Kosovo see: P. Ball et al., Killings and Refugee Flow in Kosovo March-June 1999: A Report to the International Criminal Tribunal for the Former Yugoslavia (Washington, DC, American Association for the Advcancement of Science, 2002); on Syria see M. Price, A. Gohdes and P. Ball, 'Updated Statistical Analysis of Documentation of Killings in the Syrian Arab Republic' (San Francisco, Human Rights Data Analysis Group, August 2014).

60 P. Ball, P. Kobrak and H. F. Spirer, State Violence in Guatemala, 1960-1996: A Quantitative Reflection (Washington, DC, American Association for the Advancement of Science, 1999). E. Malkin, 'Former Leader of Guatemala Is Guilty of Genocide against Mayan Group', New York Times, 10 May 2013, http://www. 


\section{Keith Krause}

nytimes.com/2013/05/11/world/americas/gen-efrain- rios-montt- of-guatemalaguilty- of-genocide.html?_r=0 (accessed 10 September 2016). The court acknowledged that the testimony and data presented by Patrick Ball were crucial in the determination.

61 Ball et al., State Violence; Malkin, 'Former Leader of Guatemala Is Guilty of Genocide'.

62 Commission for Historical Clarification, Guatemala: Memory of Silence: Conclusions and Recommendations (Guatemala City, The Commission for Historical Clarification, 1999).

63 N. Johnson et al., 'Bias in Epidemiological Studies of Conflict Mortality', Journal of Peace Research 45:5 (2008), 653-63. Other significant problems were detected with at least one of the major surveys of deaths in Iraq, which claimed that upwards of 600,000 people were killed between 2003 and 2006: M. Spagat, 'Ethical and DataIntegrity Problems in the Second Lancet Survey of Mortality in Iraq', Defence and Peace Economics, 21:1 (2010), 1-41.

64 C. Tapp et al., 'Iraq War Mortality Estimates: A Systematic Review', Conflict and Health 2:1 (2008), doi:10.1186/1752-1505-2-1; Iraq Family Health Survey Study Group, 'Violence-Related Mortality in Iraq from 2002 to 2006', New England Journal of Medicine 358:5 (2008), 484-93. Estimates in 2011 suggest that the ratio of direct to indirect deaths in Iraq may be 3:1, suggesting an additional conflict death burden: Hagopian et al., 'Mortality in Iraq Associated with the 2003-2011 War and Occupation: Findings from a National Cluster Sample Survey by the University Collaborative Iraq Mortality Study', PLoS Med 10:10 (2013).

65 For this see: D. Dessler, 'Beyond Correlations: Toward a Causal Theory of War', International Studies Quarterly 35: 3 (1991): 337-55; J. A. Vasquez, 'The Steps to War: Toward a Scientific Explanation of Correlates of War Findings', World Politics 40:01 (1987), 108-45.

66 J. D. Singer, 'The "Correlates of War" Project: Interim Report and Rationale', World Politics 24:2 (1972), 243-70. For an ambitious statement see P. Senese and J. A. Vasquez, The Steps to War: An Empirical Study (Princeton, Princeton University Press, 2008) and for a critique from within, P. Schrodt, 'Seven Deadly Sins of Contemporary Quantitative Political Analysis', Journal of Peace Research 51:2 (2014), 287-300.

67 P. Pierson, Politics in Time (Princeton, Princeton University Press, 2004).

68 A. Abbott, 'Transcending General Linear Reality', Sociological Theory 6:2 (1988), $169-86,170$.

69 See, for one example among many, Conflict Sensitivity Consortium, How to Guide to Conflict Sensitivity, Annex 1: A Selection of Conflict Analysis Tools (London, Conflict Sensitivity Consortium, February 2012), p. 42. Within the humanitarian and development communities there is increased emphasis on 'Conflict Sensitive Program Management' (CSPM). See OECD, Guidelines on Evaluating Conflict Prevention and Peacebuilding Activities (Paris, OECD, 2008), pp. 68-70.

70 M. E. Baaz and M. Stern, The Complexity of Violence: A Critical Analysis of Sexual Violence in the Democratic Republic of Congo (DRC) (Uppsala, The Nordic Africa Institute, 2010), p. 13. 
71 R. Tabib, 'Stealing the Revolution: Violence and Predation in Libya', Norwegian Peacebuilding Centre (NOREF) Report (October 2014), p. 1.

72 '[T] he overall figure in 2012 was 5,047 people killed and 5,688 injured in 2,217 attacks and clashes of various kinds', including 'casualties in terrorist attacks, operations by the security forces and their dashes with militants, ethnopolitical violence, drone attacks, inter-tribal and intermilitants clashes, sectarian dashes, religious/communal violence, cross-border attacks and clashes, criminal gangs' clashes with one another and with the security forces', Pak Institute for Peace Studies, Pakistan Security Report 2012 (Islamabad, Pak Institute for Peace Studies, 2013), p. 7. 